\title{
COMPARISON OF NYSTATIN AND FLUCONAZOLE EFFECTS IN THE HEALING OF ORAL CANDIDIASIS IN IMMUNOCOMPROMISED INDIVIDUALS: A SYSTEMATIC REVIEW
}

\author{
Milos Stepovic1, Dalibor Stajic 2 , Marija Sekulic², Milena Maricic ${ }^{3}$, Merima Goran 4,5, Zlata Rajkovic ${ }^{1}$, Nela Djonovic²,6 \\ ${ }^{1}$ University of Kragujevac, Faculty of Medical Sciences, Kragujevac, Serbia \\ ${ }^{2}$ Department of Hygiene and Ecology, University of Kragujevac, Faculty of Medical Sciences, Kragujevac, Serbia \\ ${ }^{3}$ High Health School of Professional Studies, Zemun, Belgrade, Serbia \\ ${ }^{4}$ Department of Surgery with Anesthesiology, University of Belgrade, School of Medicine, Belgrade, Serbia \\ ${ }_{5}^{5}$ Surgical Oncology Clinic, Institute for Oncology and Radiology of Serbia, Belgrade, Serbia \\ Insitute for Public Health, Kragujevac, Serbia
}

\section{POREĐENJE EFEKATA NISTATINA I FLUKONAZOLA U LEČENJU ORALNE KANDIDIJAZE KOD IMUNOKOMPROMITOVANIH OSOBA: SISTEMSKI PREGLEDNI RAD}

\author{
Miloš Stepovic ${ }^{1}$, Dalibor Stajić2 ${ }^{\text {, Marija Sekulić2 }}$, Milena Maričićc ${ }^{3}$, Merima Goran 4,5 , Zlata Rajković1, Nela Đonović2,6 \\ ${ }^{1}$ Univerzitet u Kragujevcu, Fakultet medicinskih nauka, Kragujevac \\ ${ }^{2}$ Katedra za higijenu i ekologiju, Univerzitet u Kragujevcu, Fakultet medicinskih nauka, Kragujevac \\ 3 Visoka zdravstvena škola strukovnih studija, Beograd, Zemun \\ ${ }_{4}^{4}$ Katedra za hirurgiju sa anesteziologijom, Univerzitet u Beogradu, Medicinski fakultet, Beograd \\ ${ }_{5}^{5}$ Klinika za onkološku hirurgiju, Institut za onkologiju i radiologiju Srbije, Beograd \\ 'Institut za javno zdravlje, Kragujevac
}

\begin{abstract}
Oral candidiasis is a common fungal infection of the mouth in immunocompromised individuals. It occurs when it meets ideal conditions for breeding and represents an obstacle to patients. Candida treatment consists of solving the contributing factors and in addition application of certain antifungal drugs, including nystatin and fluconazole. The evaluation of the efficacy of these drugs is important in narrowing the choice of drugs in the selection therapy. The purpose of this study was to compare the efficacy of nystatin and fluconazole in the treatment of candida albicans. For this study two databases were searched: PubMed and SCIndex - in order to find papers that are appropriate in their content in making the conclusion which meet the criteria of validity and significance. In search of papers different combinations of keywords were used based on the obtained studies that had dealt with comparing one of these two antifungal drugs. After analysing all of these studies, a number of studies that fulfilled the criteria of validity and significance reduced to 8 . The results of the studies compared have shown that the advantage in the treatment of oral candidiasis has fluconazole. The use of fluconazole in the treatment of fungal infection Candida albicans is completely safe and the patients treated with this drug showed a longer period without recurrence compared to the patients treated with nystatin.
\end{abstract}

Key words: nystatin; fluconazole; candidiasis, oral; immunocompromised host; therapeutics.

\section{SAŽETAK}

Oralna kandidijaza je uobičajena gljivična infekcija u ustima imunokompromitovanih pojedinaca. Javlja se kad postoje idealni uslovi za njeno razmnožavanje i predstavlja prepreku ya pacijente. Tretman kandidijaze sastoji se od rešavanja faktora koji doprinose njenom nastanku, a osim toga $i$ primene određenih antimikotičnih lekova uključujući nistatin i flukonazol. Evaluacija efikasnosti ovih lekova važna je u sužavanju izbora lekova u terapiji. Svrha ove studije bila je upoređivanje efikasnosti nistatina $i$ flukonazola u lečenju kandidijaze. Za ovu studiju su pretraživane dve baze podataka: PubMed i SCIndex da bi se pronašli radovi prikladnog sadržaja i doneo zaključak o ispunjavaju kriterijuma validnosti $i$ značajnosti. U pretrazi radova korišćene su različite kombinacije ključnih reči na osnovu kojih su dobijene studije koje su se bavile upoređivanjem efikasnosti jednog od ova dva antifungalna leka. Nakon analize svih ovih studija, brojne studije koje su ispunile kriterijume validnosti $i$ značaja svedene su na osam studija. Rezultati dobijeni upoređivanjem pokazali su da prednost u lečenju oralne kandidijaze ima flukonazol. Upotreba flukonazola u lečenju gljivične infekcije Candida albicans potpuno je bezbedna, a pacijenti koji su tretirani ovim lekom pokazali su duži period bez recidiva nego pacijenti tretirani nistatinom.

Ključne reči: nistatin; flukonazol; kandidijaza, oralna; imunokompromitovani organizam; terapija. 


\section{INTRODUCTION}

Oral candidiasis is a fungal infection caused by Candida albicans - fungus which is present as a part of the physiological flora of the mouth in $40 \%$ of people. There is acute candidiasis and chronic candidiasis. Acute candidiasis can be pseudomembranous, erythematousatrophic, and chronic candidiasis can be atrophic, hyperplastic and mucocutaneous. Candida albicans is the predominant species that can be isolated from the oral cavity, while the other nonalbicans Candida species are much less represented (1). Candida occurs only when there are conditions for its propagation, such as administration of antibiotics (its application leads to loss of gram-negative bacteria which are replaced by this fungus), carrying inadequate prosthetic restorations, vitamin deficiency, malnutrition, local trauma, endocrine disorders and in immunocompromised persons such as HIV-infected patients, patients with renal or hepatic transplants, patients with cancer. The treatment of this fungal infection is carried out by removal of contributing factors, treatment of systemic diseases, if it is the cause of candidiasis, and using antifungal drugs and improving oral hygiene $(2,3)$. Treatment of candida albicans is long and complicated due to biofilm that this fungus can proliferate on biotic and abiotic surfaces (4). Topical antifungal drugs (like nystatin) are typically used as the first line in treatment of oral candidiasis (5). Systematic antifungal (like fluconazole) drugs are used mostly when topical treatment of candidiasis shows no results or when risks of developing systemic infection exist (6). Duration of topical use in oral candidiasis treatment vary from 1 up to 4 weeks, and the adequate dosage (for infants, newborns, children and adults) recommendation exist $(7,8)$.

Multicentric, randomized study carried out in order to compare the effectiveness and safety of treatment with fluconazole and nystatin in 143 patients with transplanted liver is one of the studies analised for the present study. 76 patients received a daily fluconazole therapy, and 69 patients nystatin, during the first 28 days after a transplantation. Fungi of Candida colonies were shown in $25 \%$ of patients with fluconazole therapy and in $53 \%$ in patients with nystatin treatment. (9). Patients with oral candidiasis can be asymptomatic or may report pain, burning sensations, sore throat, difficulty swallowing, and/or halitosis (10-12). While oral candidiasis can usually be diagnosed through physical examination and clinical history, the European Society of Clinical Microbiology and Infectious Diseases guidelines for the diagnosis of Candida diseases recommend culturing a swab of a lesion on selective media (13-15).

This study examined the effect of two anti-fungal drugs in the treatment of oral candidiasis, fluconazole and nystatin, in order to come to a result which of the two drugs is more efficient in the removal of these fungal infections in the oral cavity. The aim of the study is to give review of the relevant clinical research about effects of nystatin and fluconazole in healing of oral candidiasis in immunocompromised individuals.

\section{METHODS}

The search used the following online library databases: PubMed, SCIndex and The Cochrane Collaboration - used for finding a comparative study. The number of studies that have been entered into consideration for this study is reduced to 8 (Figure 1). The selection was made using excluding and including criteria and assesses the validity and significance of clinical studies.

Excluding criteria were studies that are not comparing the effects of one of the drugs nystatin or fluconazole, review articles, studies done in vitro and all the studies that were not found in the full content, as well as those that do not meet the criteria of validity and significance which is why they were not taken into the account when the results were compared.

Including criteria were clinical study of the therapeutic effect, found in full text, while being made solely on the people, and the studies that have investigated the effectiveness of nystatin and fluconazole whereas it is important that they fulfill the criteria of validity and significance. These studies were used to compare the effects of drugs and in the comparison of results.

Criteria for validity and importance are both assessed for studies that were taken into consideration $(16,17)$

The criteria used to assess the validity of the study

1. Were patients on a random selection divided into experimental and control groups?

2. Were all patients who entered the study taken into account when drawing conclusions, and were they analyzed in the groups in which they were at the beginning?

3. Was the study double-blind?

4. Were groups treated in the same way except for the treatments which are tested?

5. Were the groups similar at the beginning of study?

The validity and importance of clinical studies

1. relative risk reduction

2. absolute risk reduction

3. The number of patients who should receive a new drug that would result preventing negative outcome in one of patients - Number Needed to Treat (NNT). The fulfills of criteria of significance and validity of clinical studies are shown in Table 1. 


\section{RESULTS}

Study number 1: Oropharyngeal Candidiasis in Patients with AIDS: Randomized Comparison of Fluconazole Versus Nystatin Oral Suspensions

A total of 167 patients with HIV infection and its symptoms of oropharyngeal candidiasis were randomly designated to prime the treatment of a liquid suspension of fluconazole and liquid suspensions of nystatin for a period of 14 days, after that the study continued to investigate effects after that period until day 48th when the recurrence was followed. The patients in which fungal infections were detected entered in the study and patients who did not meet these criteria were not included into the study. Also, the patients taking other types of antifungal therapy for 3 days before the study entry were excluded, as well as those with intolerance to the drug or if they had the serious problems in the liver where the liver enzymes were increased multiple times. All 167 selected patients participated in the study by the end of the study. Study was double-blind. This procedure details were not described in the study. Both treatment groups were treated in the same manner and were observed on the day 1, 3, 7, 14 as well as the 28th and 42nd day after the treatment to ascertain the incidence of recurrence. All information after each examination were recorded. 167 participants in the study were divided into two groups, 83 patients were treated with fluconazole, and 84 with nystatin. In both groups, the male-female ratio was 7:1 and all patients were of similar age - 38 .

Study number 2: Randomized Trial of Fluconazole versus Nystatin for the Prophylaxis of Candida Infection following Liver Transplantation

Immediately after the tests, the patients were randomly assigned in the center which conducted the study, in groups of ten patients. Eligible patients who entered the study were patients with liver transplantation, older than 8 years and with a transplant in one of the three hospitals that participated in the survey. If a patient experienced sensitivity to azoles, drink antifungal drugs in the first week of therapy or had re-transplantation - they were excluded from the study before a random alignment of the group. After this selection, the rest of the 143 patients participated in the study until the end of the study. Randomization was done separately in each center in blocks of 10 patients each. The way of randomization was not described properly. This criterion is not fulfilled. The patients were clinically monitored for safety and for signs and symptoms of fungal infection within $24 \mathrm{~h}$ after transplantation, at study enrollment, weekly during the first 4 weeks after the transplant, at week 8 and month 3 , and when it was clinically indicated. Patients $(n=143)$ were similar in the division into groups by gender, age and body weight. Study fulfilled the given criteria.
Study number 3: Fluconazole versus nystatin in the prevention of candida infections in children and adolescents undergoing remission induction or consolidation chemotherapy for cancer

A total of 50 patients were enrolled in a randomized study these patients were divided into two groups, where one group was treated with nystatin, and the other with fluconazole at the time of disease remission. After landing the information, the patients were randomized by computer. The patients diagnosed with cancer from 6 months to 16 years, who completed chemotherapy were eligible to enter the study. The patients $(17 \%)$ who had undergone selection, withdraw from participation in this study, while the remaining $83 \%$ stayed to the end of the study. The study was not double blind because patients knew which medication they received. Before entering the study patient's complete medical history had to be made available upon request. Data were collected on the patient's signs and symptoms of fungal infections during the course of the study. Out of 60 patients who had been selected to participate in the study, 10 dropped out of the study, while the rest of them were divided into two groups of 25 patients.

Study number 4: Efficacy, tolerability and development of resistance in HIV-positive patients treated with fluconazole for secondary prevention of oropharyngeal candidiasis: a randomized, double-blind, placebo-controlled

Patients were randomly assigned on a random selection and divided into two groups in order of consent in the study, the first received fluconazole therapy $150 \mathrm{mg}$ a week and the other was a placebo group. Of the 143 patients who entered the study, 5 patients (4 fluconazole, and 1 placebo) were not monitored, 3 patients refused further participation in the study, 2 were lost during the tracking system, so the number of patients was reduced to 138 (67 in fluconazole and 71 in placebo group). The randomization process is not explained in details. There were no significant differences in the evaluation of the data in these two groups of patients, not by HIV infection nor by the stage of infection. Therapy of patients treated with fluconazole lasted slightly longer compared to the placebo group of patients because of the prevention of a secondary infection (186 days for fluconazole and 128 days placebo). Prior to randomization, the patients were stratified into groups based on CD4 lymphocytes and the number of the previous oral candidiasis. The patients were treated for 7 days at a dose of $200 \mathrm{mg}$ fluconazole. One group was under therapy with fluconazole, and the other was a placebo control group. Placebo patients had the average age of 35 and fluconazole of 37 years and the ratio of male and female patients was similar.

Study number 5: Impact of fluconazole prophylaxis on fungal colonization and infection rates in neutropenic patients. The Canadian Fluconazole Study 
Table 1. The fulfills of criteria of significance and validity of clinical studies

\begin{tabular}{|c|c|c|c|c|c|c|}
\hline Name of the study & $\begin{array}{l}\text { Oropharyngeal } \\
\text { Candidiasis in } \\
\text { Patients with AIDS: } \\
\text { Randomized } \\
\text { Comparison of } \\
\text { Fluconazole Versus } \\
\text { Nystatin Oral } \\
\text { Suspensions }\end{array}$ & $\begin{array}{l}\text { Randomized Trial of } \\
\text { Fluconazole versus Nystatin for } \\
\text { the Prophylaxis of Candida } \\
\text { Infection following Liver } \\
\text { Transplantation }\end{array}$ & $\begin{array}{l}\text { Fluconazole versus nystatin } \\
\text { in the prevention of candida } \\
\text { infections in children and } \\
\text { adolescents undergoing } \\
\text { remission induction or } \\
\text { consolidation chemotherapy } \\
\text { for cancer }\end{array}$ & $\begin{array}{l}\text { Efficacy, tolerability and } \\
\text { development of resistance in } \\
\text { HIV-positive patients treated } \\
\text { with fluconazole for secondary } \\
\text { prevention of oropharyngeal } \\
\text { candidiasis: a randomized, } \\
\text { double-blind, placebo- } \\
\text { controlled }\end{array}$ & $\begin{array}{l}\text { Impact of fluconazole } \\
\text { prophylaxis on fungal } \\
\text { colonization and infection } \\
\text { rates in neutropenic patients. } \\
\text { The Canadian Fluconazole } \\
\text { Study }\end{array}$ & $\begin{array}{l}\text { Single-Dose Fluconazole } \\
\text { versus Standard 2-Week } \\
\text { Therapy for Oropharyngeal } \\
\text { Candidiasis in HIV Infected } \\
\text { Patients: A Randomized, } \\
\text { Double-Blind, Double- } \\
\text { Dummy }\end{array}$ \\
\hline Authors & Pons V et al & Lumbreras $\mathrm{C}$ et al & Groll AH et al & Pagani JL et al & Laverdière $\mathrm{M}$ et al & Hamza OJ et al \\
\hline \multicolumn{7}{|c|}{ The significance of the study } \\
\hline $\begin{array}{l}\text { Therapy and } \\
\text { success }(\%)\end{array}$ & $\begin{array}{c}\text { Fluconazole }(87 \\
\%) \text { Nystatin }(52.2 \\
\%)\end{array}$ & $\begin{array}{l}\text { Fluconazole (75\%) Nystatin } \\
(47 \%)\end{array}$ & $\begin{array}{l}\text { Fluconazole }(84 \%) \\
\text { Nystatin }(80 \%)\end{array}$ & $\begin{array}{c}\text { Fluconazole }(38.8 \%) \\
\text { Placebo }(9.9 \%)\end{array}$ & $\begin{array}{c}\text { Fluconazole }(46.7 \%) \\
\text { Placebo }(24.4 \%)\end{array}$ & $\begin{array}{c}\text { Two-week therapy }(88 \%) \\
\text { Single dose Fluconazole } \\
(92.8 \%)\end{array}$ \\
\hline ARR (\%) & $40 \%$ & $37 \%$ & $5 \%$ & $74 \%$ & $48 \%$ & $5 \%$ \\
\hline RRR (\%) & $34.8 \%$ & $28 \%$ & $4 \%$ & $28.9 \%$ & $22.3 \%$ & $4.8 \%$ \\
\hline NNT & 3 & 4 & 25 & 3 & 4 & 21 \\
\hline \multicolumn{7}{|c|}{ Validity of the Study } \\
\hline $\begin{array}{l}\text { Were patients on } \\
\text { a random } \\
\text { selection divided } \\
\text { into experimental } \\
\text { and control } \\
\text { groups? }\end{array}$ & No & Yes & Yes & Yes & Yes & Yes \\
\hline $\begin{array}{l}\text { Were all patients } \\
\text { who entered the } \\
\text { study taken into } \\
\text { account when } \\
\text { drawing } \\
\text { conclusions, and } \\
\text { were they } \\
\text { analyzed in the } \\
\text { groups in which } \\
\text { they were at the } \\
\text { beginning? }\end{array}$ & Yes & Yes & Yes & Yes & Yes & Yes \\
\hline $\begin{array}{l}\text { Was the study } \\
\text { double-blind? }\end{array}$ & No & No & No & No & No & Yes \\
\hline $\begin{array}{l}\text { Were groups } \\
\text { treated in the } \\
\text { same way except } \\
\text { for treatments } \\
\text { which is tested? }\end{array}$ & Yes & Yes & Yes & Yes & Yes & Yes \\
\hline $\begin{array}{l}\text { Were the groups } \\
\text { similar at the } \\
\text { beginning of } \\
\text { study? }\end{array}$ & Yes & Yes & Yes & Yes & Yes & Yes \\
\hline
\end{tabular}

In PubMed after search of keywords: oral candidiasis and fluconazole $(n$ 1045) was found
We got 20 studies. Irrelevant studies, with unfulfilled criteria of validity were excluded so number was brought to 6
SCIndex database was also searched. Using appropriate keywords we got 4 studies - but none fulfilled criteria

\section{In PubMed after search of keywords: oral candidiasis and nystatin ( $n$ - 461) was found}

We got 5 studies. Irrelevant studies, with unfulfilled criteria of validity and duplicated studies were excluded so number was brought to 1
We got 12 studies. Irrelevant studies, with unfulfilled criteria of validity and duplicated studies were excluded so number was brought to 0

We got 2 studies. Irrelevant studies, with unfulfilled criteria of validity and duplicated studies were excluded so number was brought to 1

\section{In PubMed after search of keyword:} oral candidiasis ( $n$ - 6952) was found
As including criteria, next advantage options were used for all keywords: clinical trial, full text and researches just on humans

Figure 1: Study flow chart 
The study was prospective and randomized. The patients received a dose of fluconazole in the tablets of $400 \mathrm{mg}$ per day, and the other group received a placebo once a day. Antifungal prophylaxis was started 72 hours after the start of chemotherapy. Study participants were persons aged between 18 and 80 years under cytotoxic chemotherapy suffering from acute leukemia. Patients with acute myeloid leukemia and patients with acute lymphoblastic leukemia which go through a period of remission are included and expected to be no change in neutrophils less than $0.5 \times 109$ neutrophils / L in the period of 7 days. A total of 266 patients enrolled into study after 8 were excluded. In this paper, there is data that the study was a double-blind, however nowhere is described details of method. The groups were tested in the same way. Basic status of a patient was divided into two treatment groups using Chi-squared tests and t-tests. The status of colonization at the end compared with the MantelHaenszel test stratified by basic status of colonization. The treatment effect of the antifungal infection was evaluated and tested via the logistic regression function. Study groups were similar with the exception of a small number of patients assigned to fluconazole and the placebo group (19 versus 6), the average time duration of the study (22 versus 19), and the mean number of days with an absolute neutrophil count $\leq 0.5 \times 109$ / L (14 vs. 11 ), the average age of patients in the fluconazole was 47.6 , while it was 45 for the patients in the placebo group.

Study number 6: Single-Dose Fluconazole versus Standard 2-Week Therapy for Oropharyngeal Candidiasis in HIV Infected Patients: A Randomized, Double-Blind, Double-Dummy

The patients were randomized in a ratio of 1: 1 according to a specified code. The total number of participants was 220. The patients took randomized treatment, oral therapy fluconazole $750 \mathrm{mg}$ ( 5 tablets of $150 \mathrm{mg}$ ) or placebo one pill, once per day (or the recommended dose of fluconazole one tablet of $150 \mathrm{mg}$ ) for two weeks. The patients entered into the study if they were older than 18 years and if they have confirmed the presence of HIV infection through ELISA test or Western blot assay, if there were visible lesions and symptoms of oropharyngeal candidiasis. During the study, the patients were in the same group, and the data on their balances are designed and evaluated. The pharmacist who was giving the medication knew the code of drugs that were randomized and assigned to patients, while neither the participants nor the doctors did not know what medications were received/given. After the first day of the basic visit, the patients had a follow-up examinations on the day 3, or 4, 6 or 7 and 14, at the end of the study, and after each control visit patients estimated side-effects of treatment, as slight, moderate and severe. In patients who had a two-week treatment the average age was 35 years, and the patients with a single dose of fluconazole it was 34 years. Body mass index of the patients had an average of 20.9. There were two groups with 110 patients each.

Study number 7: Candida albicans infection in patients with oral squamous cell carcinoma

The order of both groups (30 in study and 30 controls) was determined by the order of arrival to treatment so that we can conclude that it was on a random selection. The criteria that were used are diagnosed with squamous cell carcinoma of the oral cavity and those patients who did not have this diagnosis did not enter the study. In the decision making all data from all the patients who participated in the examination were taken, whereby the groups did not change. The study was not double-blind due to insufficient data on the method of administration. Mycological testing material was collected from the surface of the swab cancer while in patients in the control group the swabs were taken from the macroscopically benign changes. For fungus identification germination Mackenzie test was used. The study group had a number of 30 patients (24 males and 6 females), mean age of 61.47 years (41-81 years) who were clinically and histologically diagnosed with squamous cell carcinoma of the oral cavity. The control group consisted of 30 subjects (16 males and 14 females), mean age of 54.53 years ( $16-83$ years).

\section{DISCUSSION}

The appearance of candidiasis in immunocompromised individuals such as patients with HIV infection, patients with liver transplantation, patients on chemotherapy and patients with leukemia is one of the problems of these patients and comparing the effectiveness of drugs in preventing of this fungal infection is important in improving the quality of life of those patients and solving opportunistic infections. One of the more common treatment of this fungal infection is therapy with fluconazole and nystatin, and the comparison of these drugs is actually essential in selection of adequate fungal therapy.

The emergence of Candida infection in patients with squamous cell carcinoma has been demonstrated using the techniques of the swab from the surface of cancer, it has been found significantly higher in the presence of the fungus in a patient with oral cancer $(30 \%)$ than in the control group of patients with benign lesions of the oral mucosa. On the importance of testing fungal colonization of the oral cavity in patients with carcinoma of the head and neck shows results of studies in which it was determined that patients with a recent colonization were much more likely to occur oral candidiasis during the radiation therapy (1).

The comparation of efficacy of fluconazole and nystatin in HIV-infected patients showed that the 
treatment of the persistent fungal infections was successful by applying both of these drugs, but fluconazole had an advantage in the number of cured cases $(25 \%)$ as well as for being logged in a smaller number of relapses when this drug was used. Also, the use of fluconazole for a long period in these patients is fully justified, because after its long-term use, the resistance to the drug was not reported $(18,19)$. Comparing the effectiveness of a single dose of fluconazole in relation to a two-week treatment with a lower dose of this drug has shown that in addition to the method of use of one, a higher dose of fluconazole is simpler and less costly to use than a standard two-week treatment, while the treatment effect was even better with the percentage of cured patients of $87.5 \%$ (20). Studies dealing with comparing the effectiveness of the above-mentioned drugs in patients with liver transplantation, as a result of the research, demonstrated that fluconazole was more effective in prevention of infection in transplant patients. During prophylaxis, Candida was absent in $75 \%$ of patients treated with fluconazole, whereas in patients treated with nystatin this percentage was lower, 47\%. For all-time monitoring of the effectiveness of drugs, the number of infection increases after cessation of the therapy was higher in patients treated with nystatin (21). When testing the safety of fluconazole and nystatin in the prevention of Candida infection in children and adolescents during remission of cancer it has been demonstrated that the efficacy of these two medicaments are similar and that both are safe. But in case of potential resistance, fluconazole prophylaxis is limited to patients in whom prolonged and severe neutropenia and mucositis are expected. The daily dosage for the prophylaxis of these patients in the research is shown at least $8 \mathrm{mg} / \mathrm{kg}$ (22). The impact of the treatment of prophylaxis of fluconazole in the fungal colonization at neutropenic patients compared to the placebo group has shown that fluconazole reduces total number of ill patients and that its use is effective (23).

Based on the analised studies $(n=8)$ that meet the criteria of significance and the validity the conclusion is that the antifungal drug nystatin has a weaker effect on the healing and reducing the number of relapses in patients suffering from fungal disease caused by Candida albicans. Unlike nystatin, much better results are demonstrated by fluconazole with significantly greater number of patients cured and fewer relapses to all groups of immunocompromised persons who were examined in this study (patients on chemioterapy, patients with HIV infection, patients with liver transplant). Also it has been proven to be a drug that in such cases does not give significantly adverse reactions. In comparison to the placebo control group, the number of patients treated with fluconazole showed greater efficiency and recovery percentage.
Based on the result of the review article obtained by searching the Cochran library, which dealt with comparing the effects of nystatin and fluconazole as well as nystatin and placebo and nystatin and amphotericin B, in the prevention and treatment of infections caused by Candida albicans in immunocompromised individuals (patients on chemioterapy suffering from cancer, liver transplantation, patients infected with HIV) it can be concluded that nystatin can be used as a treatment of choice in treatment of these infections in immunocompromised individuals due to an insufficient efficiency. This review article compared 14 studies wherein the prophylaxis was given in 12 studies and as a therapy in the 2, wherein nystatin was given as a therapy, and the control group were placebo, fluconazole and amphotericin b. Of the 14 studies, 10 have engaged in comparing nystatin and fluconazole, 3 studies were done by comparing the placebo and nystatin and 1 study looked at by comparison of nystatin and amphotericin b. As a conclusion of this study, it was shown that fluconazole is the most effective in prevention of infection and in being safe for use. The absolute risk in curing these patients, treated with fluconazole compared to Nystatin is 0.40 , and the absolute risk reduction of colonization is 0.50 (24). Comparing this review and the results obtained from clinical studies analyzed in this paper leads to the same conclusion that fluconazole is safer, more efficient and should be used as a drug of choice in treatment of immunocompromised patients.

\section{CONCLUSION}

In treatment of infections caused by Candida albicans both of drugs have the effect - fluconazole and nystatin. Based on this study, the conclusion is that the antifungal drug fluconazole has a better and longer-lasting effect in the prevention of candidiasis in immunocompromised individuals, and its use is completely safe in the treatment of these recurrent infections

\section{CONFLICT OF INTEREST}

There is no conflict of interest in this paper.

\section{REFERENCES}

1. Cankovic M, Bokor-Bratic M. Infekcija kandidom albikans kod bolesnika sa oralnim planocelularnim karcinomom. Vojnosanit pregl 2010; 67:766-70.

2. Janković Lj. Oralna medicina. Beograd: Zavod za udžbenike i nastavna sredstva, 2007.

3. Gulati M, Nobile CJ. Candida albicans biofilms: development, regulation, and molecular mechanisms. Microbes Infect 2016; 18:310-21.

4. Akpan A, Morgan R. Oral candidiasis. Postgrad Med J. 2002; 78:455-9. 
5. Epstein JB, Polsky B. Oropharyngeal candidiasis: a review of its clinical spectrum and current therapies. Clin Ther 1998; 20:40-57.

6. Niimi M, Firth NA, Cannon RD. Antifungal drug resistance of oral fungi. Odontology 2010; 98:15-25.

7. Gøtzsche PC, Johansen HK. Nystatin prophylaxis and treatment in severely immunodepressed patients. Cochrane Database Syst Rev 2002; CD002033.

8. American Medical Association, AMA Department of Drugs. AMA Drug Evaluations. 3rd ed. Littleton: PSG Publishing Co., Inc., 1977.

9. Lumbreras C, Cuervas-Mons V, Jara P, et al. Randomized trial of fluconazole versus nystatin for the prophylaxis of candida infection following liver transplantation. J Infect Dis 1996; 174:583-8.

10. Lyu X, Zhao C, Yan ZM, Hua H. Efficacy of nystatin for the treatment of oral candidiasis: a systematic review and meta-analysis. Drug Des Devel Ther 2016; 10:1161-71.

11. Nenoff P, Krüger C, Schaller J, Ginter-Hanselmayer G, Schulte-Beerbühl R, Tietz HJ. Mycology - an update Part 2: Dermatomycoses: Clinical picture and diagnostics. JDDG: Journal der Deutschen Dermatologischen Gesellschaft 2014; 12:749-77.

12. Picciani BL, Michalski-Santos B, Carneiro S, et al. Oral candidiasis in patients with psoriasis: correlation of oral examination and cytopathological evaluation with psoriasis disease severity and treatment. J Am Acad Dermatol 2013; 68:986-91.

13. Miller DJ. Diagnosis and management of Candida and other fungal infections of the head and neck. Curr Infect Dis Rep 2002; 4:194-200.

14. Cuenca-Estrella M, Verweij PE, Arendrup MC, et al. ESCMID* guideline for the diagnosis and management of Candida diseases 2012: diagnostic procedures. Clin Microbiol Infect 2012; 18:9-18.

15. Pons V, Greenspan D, Lozada-Nur F, et al. Oropharyngeal candidiasis in patients with AIDS: randomized comparison of fluconazole versus nystatin oral suspensions. Clin Infect Dis 1997; 24:1204-7.
16. Sackett DL, Straus SE, Richardson WS. Evidencebased medicine: how to practice and teach EBM. 2nd ed. New York: Churchill Livingstone, 2000.

17. Sheridan DJ, Julian DG. Achievements and limitations of evidence-based medicine. J Am Coll Cardiol 2016; 68: 204-13..

18. Pagani JL, Chave JP, Casjka C, Glauser MP, Bille J. Efficacy, tolerability and development of resistance in HIV-positive patients treated with fluconazole for secondary prevention of oropharyngeal candidiasis: a randomized, double-blind, placebo-controlled trial. J Antimicrob Chemother 2002; 50:231-40.

19. Hamza OJ, Matee ML, Brüggemann RJ, et al. Singledose fluconazole versus standard 2-week therapy for oropharyngeal candidiasis in HIV-infected patients: a randomized, double-blind, double-dummy trial. Clin Infect Dis 2008; 47:1270-6.

20. Groll AH, Just-Nuebling G, Kurz M, et al. Fluconazole versus nystatin in the prevention of candida infections in children and adolescents undergoing remission induction or consolidation chemotherapy for cancer. J Antimicrob Chemother 1997; 40:855-62.

21. Laverdiere M, Rotstein C, Bow EJ, et al. Impact of fluconazole prophylaxis on fungal colonization and infection rates in neutropenic patients. J Antimicrob Chemother 2000; 46:1001-8.

22. Gøtzsche PC, Johansen HK. Nystatin prophylaxis and treatment in severely immunodepressed patients with nystatin. Cochrane Database Syst Rev 2014; CD002033.

23. Langley RG, Elewski BE, Lebwohl $M$, et al. Secukinumab in plaque psoriasis: results of two phase 3 trials. N Engl J Med 2014; 371:326-38.

24. Mersal A, Alzahrani I, Azzouz M, et al. Oral nystatin versus intravenous fluconazole as neonatal antifungal prophylaxis: non-inferiority trial. J Clin Neonatol $2013 ; 2: 88-92$. 